Psicologia \& Sociedade; 20 (2): 287-296, 2008

\title{
THE "FASCIST" DISCOURSE IN COMPUTER MEDIATED COMMUNICATION: THE "DUAL STRATEGY" MODEL OF THE ITALIAN EXTREME RIGHT ${ }^{1}$
}

\author{
Luca Tateo \\ University of Salerno, Salerno, Italy
}

\begin{abstract}
The study is about the identity construction of Italian Extreme Right groups in different Computer Mediated Communication (CMC) environments. Rhetoric Psychology and Critical Discourse Analysis joint approaches are used to analyse two websites and two newsgroups of extreme right. The results confirm Billig's hypothesis that such groups play a dual communication strategy in Computer Mediated Communication, addressing in different ways to the outgroup and the ingroup. This communication strategy has two different functions. In self-presentation towards the outgroup, the emerging group identity fulfils the search for a wider social legitimation, consensus and recruiting. In the ingroup communication, the emerging identity construction answers to the need for preservation of group cohesion and positive self-image.
\end{abstract}

KEYWORDS: CMC; Rhetoric Psychology; group identity; extreme right movements.

\section{O DISCURSO “FASCISTA” NA COMUNICAÇÃO MEDIADA POR COMPUTADOR: O MODELO DE "ESTRATÉGIA DUPLA" DAEXTREMADIREITAITALIANA}

RESUMO: Este estudo é sobre a construção da identidade dos grupos Italianos de Extrema Direita em diferentes ambientes de Comunicação Mediada por Computador (CMC). As duas abordagens, Psicologia Retórica e Análise Crítica do Discurso são usadas para analisar dois websites e dois grupos de notícias de extrema direita. Os resultados confirmam a hipótese de Billig de que tais grupos desempenham um duplo papel na estratégia de comunicação na Comunicação Mediada por Computador, dirigindo-se de diferentes maneiras ao grupo externo e ao interno. Esta estratégia de comunicação tem duas funções distintas. Na auto-apresentação feita em direção ao grupo externo, a identidade emergente do grupo satisfaz a busca para uma legitimação social, consenso e recrutamento mais amplos. Na comunicação com o grupo interno, a construção da identidade emergente responde a necessidade de preservação da coesão do grupo e de uma auto-imagem positiva.

PALAVRAS-CHAVE: CMC; Psicologia Retórica; identidade de grupo; movimentos de extrema direita.

Since the 80's, Extreme Right (ER) movements have developed a world wide network of web sites and newsgroups to bypass social censorship against the fascist ideology, racism, violence and hatred expressed in their on-line texts. During the last two decades, European society has witnessed a resurgence of political violence and the rise of political movements which recall extreme right ideas, like Le Pen's Front National in France, Heider's FPOE in Austria, the Pym Fortuyn movement in the Netherlands or Zhirinovsky party in the Russian Republic (Evans et al., 2001; Schmidt, 1993). According to many researchers, traditional media for building consensus have been integrated by the use of Computer Mediated Communication (CMC) tools (Hoffman, 1996; Karmasyn, Panczer, \& Fingerhut, 2000; TadmorShimony, 1995). The Internet allows minority and geographically scattered groups to cooperate for a common goal. It also weakens the forms of central governance put in practice by control authorities. Dyson (1997) states that for these characteristics the Internet is an appropriate medium for "conspiracy", and thus has been rapidly adopted by a fragmentary constellation of ER groups, in opposition to the attempts of national governments to control and repress their activities (Bernstein, 1996; Karmasyn et al., 2000).

The present study analyses the activities of Italian ER groups on the Internet, highlighting ER identity construction strategies in different CMC environments.

The theoretical framework consists of an integration of Rhetorical Psychology (RP) (Billig, 1996) and Critical Discourse Analysis (CDA) approaches (Fairclough, 1995, 2000, 2001; Flowerdew, 2004). We chose to carry out an interpretative analysis of discourse in search of the "implicatures" (Flowerdew, 1999), presuppositions 
(Wodak, 2002) and rhetorical devices (Billig, 1977) through which ER groups give an account of their public and private identity and their vision of society. The multiplicity of possible interpretations of their discursive utterances is narrowed by taking the larger context and the cotext into account (Wodak, 2002). To ensure a more comprehensive analysis we also need to relate to different approaches and theories from neighbouring disciplines. A deep understanding of ER discourse needs to refer to sociological, historical, and political claims as well as socio-psychological concepts because the phenomenon is very complex (Wodak, 2002).

The analysis of discursive productions in two web sites and two newsgroups seeks to confirm Michael Billig's hypothesis of different identity strategies in CMC environments belonging to the outgroup $-\mathrm{v}$ - ingroup communication salience. Analysis also shows how, from the perspective of situated identity, such communication strategies build two identity patterns. The first emerges in the context of a Self-presentation addressed to the outgroup in search of wider social legitimisation, participation and consensus. The second in the context of ingroup communication, relates to the search for group identity preservation and group cohesion.

\section{Theoretical Framework}

Since the so called "renaissance of rhetoric" (Perelman \& Olbrechts-Tyteca, 1969) the interests of social psychology and pragmatics have progressively overlapped, thus establishing common research objects that is discourse and argumentation as we have summarized in Figure 1.

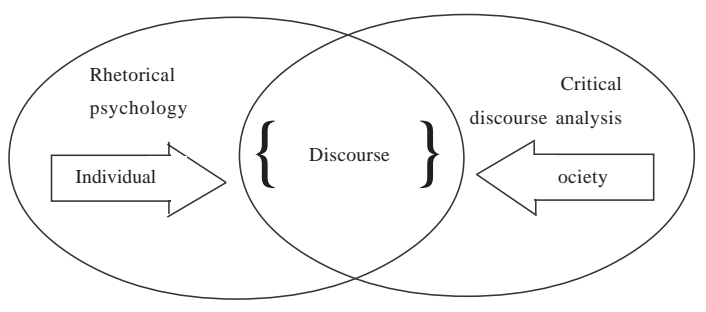

Figure 1. Theoretical intersection of RP and CDA

In particular, there was a conjoining, in discourse and forms of argumentation, of individual high level cognitive processes and social processes (Billig, 1996; Wodak, 2002).

$\mathrm{RP}$ is based on the principle of argumentation as a form of thinking (Billig, 1996). In English, the word "argument" has a double meaning: discussion, controversy, or else and individual reasoning, presentation of a discourse (Billig, 1996). Thus, according to Billig, high level cognitive processes represent an inner debate between different positions with respect to a given object. In thoughts, attitudes, beliefs and emotions there are always couples of opposite positions arguing one against the other.

The outcome of this process is the prevailing of one position over another (Billig, 1996). But the achievement of a position always implies the refusal of the opposite position. The other side of the coin is that this process of positioning has also a social value. In fact, expressing an attitude towards a social object means becoming part of a wider social controversy (Billig, 1996). Argumentation is the process associated with both individual and social processes (Figure 2). It consists mainly of a dialectic confrontation between logoi - arguments grounded in common sense - and antilogoi - refuting arguments. Thus, studying forms of argumentation in public discourse, which are basically rhetoric forms, is a way of analysing the relationship between the individual and culture (Billig, 1996).

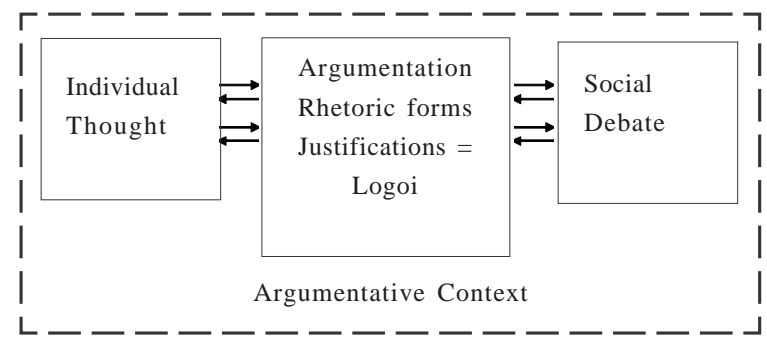

Figure 2. Relationship between individual thought and social discourse (Billig, 1996)

CDA is instead based on the idea of the reflexive relationship between text context and society (Flowerdew, 1999). CDA develops the analysis of the dialectic relationship between "discourse and social practices" (Fairclough, 1995, 2000, 2001; Flowerdew, 2004, p. 582). Discourse is an integral part of all social processes and is realized in various semiotic forms, such as language, image and gesture. Discourse is a system of texts organized in standardized forms of language - genres - and belonging to a social order of discourse. In CDA, like in RP, discourse is a form of action contextualized in social practice, involving status and power relationships. Power is not equally distributed in society and is the object of a struggle between majority and minority. The traces of the struggle are crystallized in public discourse. Rather, discourse is the place where social inequality is "naturalized" (Flowerdew, 2004, p. 582), as, for instance, in the case of gender markers in CMC language (Herring, 1996). CDA aims to analyse common knowledge in discourse by discovering expressions of social inequality, power relationships, group dynamics and social change (Fairclough, 2000). 
In addition a convergence of the common object of study, RP and CDA share some methodological aspects, such as thematic analysis, analysis of rhetoric forms and the study of argumentative chains (Billig, 1996; Wetherell, Taylor, \& Yates, 2001). These methodologies seem very useful in the study of CMC products, in which is very difficult to study communication processes focusing on the author and the audience which are often undifferentiated and anonymous (Gerstenfeld, Grant, \& Chiang 2003). Studying psychological aspects, such as the identity, attitudes and goals of ER activists through computer networks raises many methodological problems with respect to the sampling, responsiveness, and generalisation of conclusions. Besides, as Glaser, Dixit and Green (2002) point out, "special ideological populations" like ER movements are difficult to examine through interviews or direct observation, because they are very suspicious of any authority or outsider. It is very difficult to establish whether the expression of their thoughts and attitudes are tailored to the presence of the researcher.

That's why we choose to use a combination of RP and CDA approaches to study relevant aspects of identity construction in the ER discursive production on the Internet. Nevertheless, to minimize critical baseness and to avoid simply politicizing, instead of accurately analyzing the implicit in RP and CDA interpretative analysis, we applied the principle of triangulation (Wodak \& Meyer, 2001). We attempted to integrate the linguistic dimension and to include more or less systematically the sociopsychological, political and sociological dimension in the analysis and interpretation of the ER discourse.

\section{Discursive Nature of ER Image: The Dual Strategy Hypothesis}

The life of political groups can be described as a network of social practices whose core aim is to seek consent, social legitimation and group cohesion (Fairclough, 2001, 2000). Such practices, constituted in various genres of discourse (reunions, distribution of fliers, commemorations, etc.), pass through the reformulation of common historical knowledge, also know as "revisionism", that becomes the battlefield of a "semiotic struggle", a "war of words" as defined by Flowerdew (1998). The use of CMC environments has integrated those traditional genres of discourse in the communication of ER groups, creating a "multivoiced" dialogue of the web pages' of various authors and evidencing a distinctive feature of "intertextuality" (Markova, 2003; Wodak, 2002). In CMC discursive dynamics also assume peculiar characteristics. The simplicity with which it is possible to establish links between Internet web-sites facilitates the constitution of virtual networks of groups brought together by common motivations and affairs, who in this case belong to the political area of ER (Burris, Smith, \& Strahm, 2000).

According to the CDA approach, we attempt to provide an analysis of communicative and identity strategies, and to give a credible interpretation amongst all the potential readings of these texts. Also if questionable, the analysis presented here is supported by contextual information, which helps in the selection of some meaningful elements (Flowerdew 1999) trying to resolve the ambiguity which is a favorite device in political discourse (Lakoff, 1990).

Challenging the taboos created in the second postwar period, ER groups put forward some common sense assumptions in an attempt to modify public opinion's "latitudes of attitudes" (Billig 1996; Sherif \& Hovland, 1961) and "destroy the social basis" (Billig, 2001, p. 271) with restraints against authoritarianism, xenophobia, antiSemitism and political violence. As carriers of a minority ideology, unacceptable to common sense, such groups play out their role in the theater of the semiotic struggle using different strategies. They mask their messages by using unpolarized language, face-value denials and selfdefinitions, or by arguing to the effect that the previously undisputed reality of ER crimes become a matter of belief (Billig, 1996). The clearest example of such strategies is represented by heterogeneous movements, composed by of historians, politicians and publishers, called "historical revisionism" and "negationism" that re-phrase events of World War II in a more favorable light for ER ideology, to the extent of denying such historical facts as the mass exterminations which occurred under Nazism (Shermer \& Grobman, 2000). As suggested by Karmasyn et al. (2000), the authors of ER material, especially web sites, often try to justify their statements through a system of mutual quotations, to give the impression that there exists one "scientific community" that shares those ideas.

According to Billig (2001), the communication strategy of ER groups follows a "dual strategy": a "High road' (HR) in public, which introduces a respectable and democratic self image, and a "Low road" (LR) in private, which circulates much more extreme and violent messages. In the case of $\mathrm{CMC}$ environments, talking to a wide and undiversified audience of web sites, they would adopt a HR strategy of communication, using unpolarized language and arguments with the aim of overturning and changing the common sense view (Figure 3).

In ingroup communication, such as that espoused by ER newsgroups, which are addressed to a narrow public of registered voluntary members, the prevailing strategy of communication is LR, with the use of strongly polarized language, a constant recall to the identity and cohesion of the group as well as a clear negative definition of the outgroup. Such a double strategy contributes to 
the emergence of different discursive constructions of ER group identity, in which it is possible to disclose the pragmatic function of the texts produced: self-legitimating toward the outgroup and increasing the cohesion toward the ingroup. To this end, ER groups use sophisticated techniques of persuasion in their communication through web sites, aimed at legitimating and recruiting (McDonald, 1999).

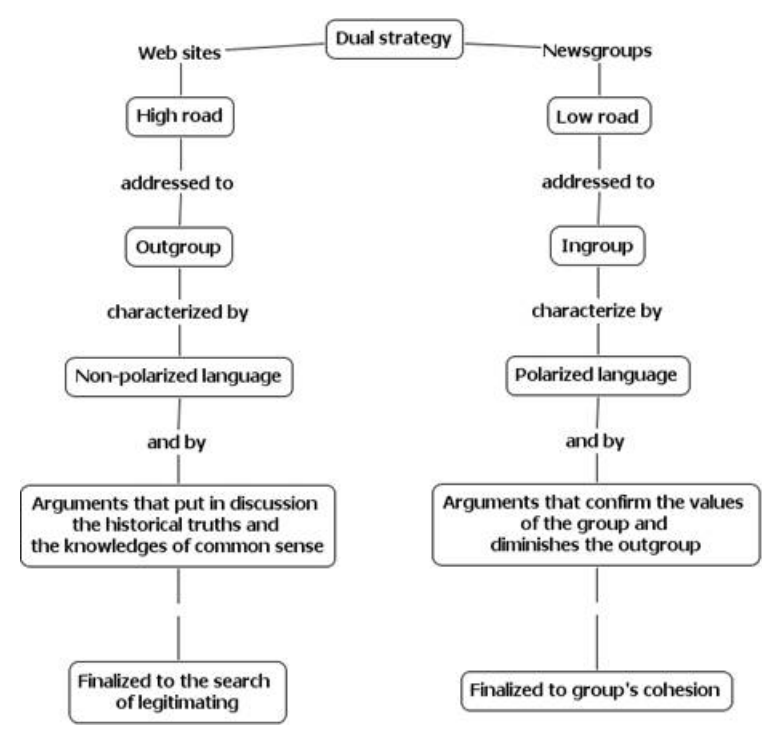

Figure 3. Dual strategy model

\section{The Extreme Right and the Internet: The Web of Hatred}

The Internet is a medium that makes it very easy to establish relationships between groups and reach a wide audience. Computer networks became a very popular communication tool amongst marginal and extremist groups, because of their lower costs, the mostly total anonymity, and their user friendliness. ER groups immediately became aware of the potential of the Internet to support coordination, proselytism and propaganda. In the early ' 80 s they were already building the so called "web of hatred" (Gerstenfeld et al., 2003; Hoffman 1996; Levin, 2002; Lewis Rand, 1996; Stern, 1999).

Furthermore, on the Internet it is practically impossible to exert any type of control or censorship of ER publications (Gerstenfeld et al., 2003). In Europe, web sites hosting violent or racist messages or violating laws against fascist propaganda have been repeatedly closed by the police. Nevertheless, the web sites soon reappeared on web server based in the United States, where the rules are more indulgent and sites are protected by the First Amendment, typically laying claim to freedom of speech whilst communicating racist and violent messages (Wodak,
2002). In Italy, for instance, the webmaster of the " $\mathrm{Co}$ munismo" web site, which despite its name, belongs to ER activists, simply moved to a new Internet provider once the police closed the site and the author simply re-published a copy of the web pages he had previously saved on his own hard disk (Cavina, 2001, p. 77).

The history of ER communication on the Internet began on March 1984, when George P. Dietz, a publisher of racist and anti-Semitic literature, created the first " white supremacist" Bulletin Board System (BBS) called "Info. Dot Information Network" or "Liberty Bell Net". Still in 1984, Tom Metzger, founder of White Aryan Resistance (WAR) opened the first racist organisation's BBS. During the late'80s, Louis Beam, representative of Aryan Nation, opened the first network of racists BBSs. In 1991 the first "negationist" BBS, based in Portland, was born: the "Banished CPU" of Dan Gannon. In Europe, the first neo-Nazi's BBS "Thule" was born in Germany in 1992 (Lewis Rand, 1996, p. 61). The first "white supremacist" web site is "Stormfront", realized by Don Black in 1995 (Bernstein, 1996, p. 228). From that time, the Internet became a very common tool for ER groups supporting the creation of international networks (Burris et al., 2000; Gerstenfeld et al., 2003; Hoffman, 1996; Schmidt, 1993).

Political and sociological literature offers many studies of United States hate groups on the Internet (Burris et al., 2000; Gerstenfeld et al., 2003; Tateo, 2005). Franklin (2006) assesses more than 2000 hate group web sites, 10 weblogs, 27 mailing list owners, more than 130 newsgroups, 6 IRC servers, and 10 webrings ${ }^{2}$ in the English language, that according to the author "advocate violence against, separation from, defamation of, deception about, or hostility toward others based upon race, religion, ethnicity, gender or sexual orientation" (Franklin, 2006).

In Europe the history of the use of computer networks by ER groups has not been studied enough (Karmasyn et al., 2000). The Italian ER network includes web sites, forums, mailing lists and IRC. Tateo (2005) assessed that in Italian language exist at least 5 newsgroups and more than 150 hate groups' web sites.

However, few studies about the Italian context exist and the story of these web sites has not yet been written. Cavina (2001) analyzed the web sites of Italian ER and their relationships with other groups in European countries and in United States from a sociological point of view. The main Italian networks of ER web sites are the "Foedus Italicum" (Figure 4) and the "Dux Award" (Cavina). The first is a webring claiming to be an "italic on-line alliance"3 collecting web sites of political movements, a history of World War II, and a history of Fascism. The "DuxAward" is a type of good quality ribbon for the best Fascist web sites (Cavina, 2001; Tateo, 2002, 2005). 


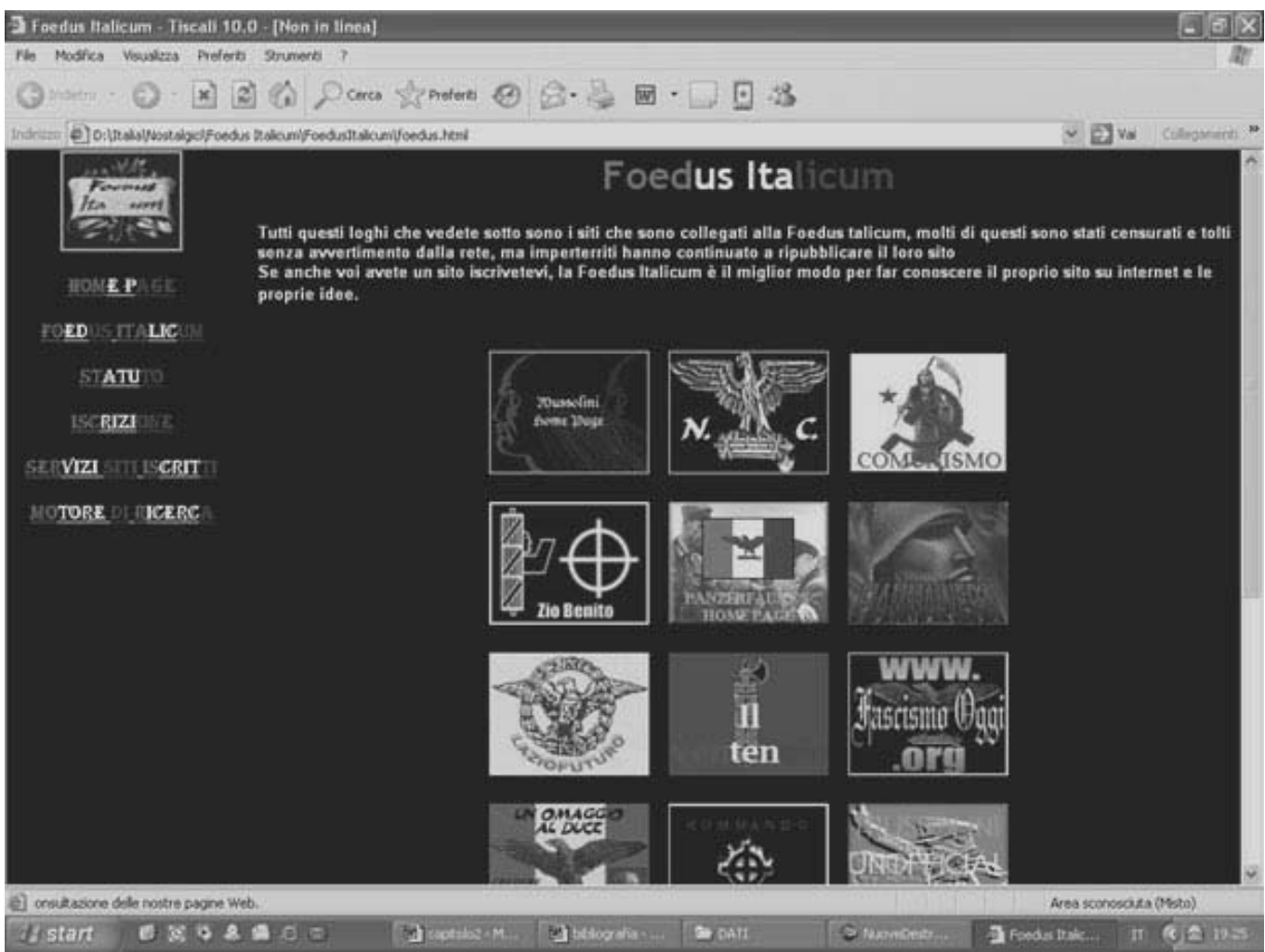

Italian ER networks are often linked to international ones. Some Italian web sites are for instance affiliated to the "Euronat Jeunesse" network, that includes ER movements like the German "Deutsche Volksunion", the Flemish "Vlaams Blok", the Slovakian "Slovenska Narodna Strana", and so on (Cavina, 2001). Italian ER sites are also affiliated to international webrings. The sites of the Italian movements: "Movimento Sociale Italiano", "Forza Nuova", "Kommando Fascista" and "Mussolini Home Page "Forza Nuova" are included in the "Webring Resist@nce", founded by the French group "Unitè Radicale". This web ring, comprising 85 members, aims to "support the presence of activists on the Internet” (Cavina).

\section{Corpus}

Both the web sites and newsgroups of the ER groups are "systems of genres" (Bazerman, 1994; Flowerdew, 2004) containing innumerable textual genres. Such heterogeneity obviously involves very different lengths of texts, as well as a wide variety of styles and forms of discourse, including life stories, opinions, multimedia reproduction of historical documents, newspaper articles, personal journals, letters, poetries and song texts, images, comics, humor and irony, videogames based on violence advocacy against minority groups (Billig, 2001; Franklin, 2006; Gerstenfeld et al., 2003; Tateo, 2005).

The corpus of data is constituted by the pages of two Italian language ER web sites, for a total of 3.407 units of analysis (UA), and from the messages posted in two ER Italian language newsgroups, for a total of 2.956 UA, contained in a total of 233 messages posted between March 28th 2003 and March 13th 2004.

In an attempt both to preserve the ecological validity of the corpus and to simplify the process of analysis, the paragraph, delimited by the special character of "return" $(\wedge \mathrm{P})$ inserted from the same authors of the pages or in the messages, and which points out a thematic and pragmatic change in the text has been chosen as the UA (Annese, 2002; December, 1996).

In detail, the corpus is composed of:

1. The web sites: (a) Carpe diem, quarterly on-line review of the cultural association "the White Buck" which hosts some pages edited by the cultural association "Amigos de Leon Degrelle", reviews of ER ("The legion"; "Nothus"; "Offensive"; "Otto"), and pages of the organizations of the Italian Social Republic's veterans; 
(b) Historical-cultural association Italy-RSI which contains an anthology of original texts and studies on the Italian Social Republic (RSI) and is in partnership with a network of revisionist sites named: "History and US. To tell the '900? Let's tell everything!'. The site is a rich repository of documents on the history of the RSI, with links to other sites of the same type, to veterans' organizations, army organizations associated with the RSI and to some revisionist magazines.

The theoretical interest basis for the analysis of the two sites related to the fact that they are very popular in the ER area and belong to the main typologies of Italian ER groups: the first is a group that develops political activity and publications expressly recalling itself to ER ideology, whilst the second is a group of veterans and supporters of the RSI of Salò (Tateo, 2002, 2005).

2. The newsgroup: (a) free. it.politica.destra.sociale: 123 messages posted between August 11th 2003 and March 13th 2004; (b) it.politica.destra: 174 messages posted between March 28th 2003 and April 14th 2003.

The two newsgroups belong to different newsgroups hierarchies, and they are amongst the few Italian speaking discussion forums that expressly treat themes of ER (Tateo, 2005).

\section{Analysis of Discursive Dynamics}

The first element object of verification is the presence, in the two different environments of CMC, of linguistic and argumentative patterns expected by the " $d u a l$ strategy" hypothesis (Billig, 2001; Tateo, 2006).

\section{HR Strategy for the Outgroup: Legitimation Through the Revision of History}

In those web sites, addressed to the outgroup and whose core aim is social legitimation, an argumentative strategy which seeks to change common sense knowledge can be clearly found. The use of terms belonging to other contexts serves the purpose of re-positioning the activists of ER in positive terms (Tateo, 2006), as in the following examples:

$<$ The legionaries of such epic resistance were confined in concentration camps to Taranto, Scandicci, Coltano etc. ${ }^{4}>$

$<$ we publish Dozens of witnesses about our "Desaparecidos". Resistance again Fascism is it a Movement for the liberty or for the sovietisation of Italy $?^{5}>$.

The utterances delineate a process of victimization through the embezzlement of historical framing. Terms formerly reported to the victims of Fascist regimes during World War II and the Argentine dictatorship, as “concentration camps" and "desaparecidos", are attributed to the fascist activists of the World War II, attributing to them the role of actual victims.

The historical reconstruction of facts of World War II is presented through a strategy of language turn-around, calling into question the validity of shared beliefs and attitudes toward Fascism. The authors of the texts use terms such as "civil war", "slaughter", "martyrs", "ambush", "heroes", which traditionally belong to the vocabulary of Allied rhetoric. In this way, they compare the positions of the two factions, Fascists and antiFascists, with the aim of reversing the roles of "good" and "evil".

The representation of Fascism and its activists, to which common sense attributes a negative value, thus becomes "debatable" as soon as the historical facts on which such an evaluation is based are called into doubt (Billig, 1996, p. 362). Through the use of the rhetorical device of "truth will out" (Gilbert \& Mulkay, 1984), the common sense version of the history of World War II is undervalued as an "oleography" or "legend". ER groups claim to promote the true, unheeded voice of the history, as in the following utterance:

<let's give a chance to the future interpretation! Let's tell also the "other history". And also if it would not be all true or all correct it will be always a possibility more to understand as the things went. For the one that will honestly want to listen ${ }^{6}>$

Once the common sense representation of Fascism has been denied, the argumentation moves from the historical context to the contemporary one. If the issue of the fascist ideology of the past is considered controversial, in this way, so too can the ideology of the heirs of the Fascism also be made controversial.

Common sense discourse is overturned and what was a hate ideology becomes an absolute value sheltered from argumentative attack. In the following utterance, for instance, the use of the term "faith" transfers Fascism from the category of ideology to that of transcendent belief and therefore non-historical:

$<$ Therefore, "Fascisms " are faith and reason, passion and good sense. Inflexible faith that spiritually crosses every human understanding, and simple reasoning that brings back the dreams to the sense of their real and possible realization ${ }^{7}>$

In other words, in the communication toward the outgroup, the objective is to introduce a different truth from that which is commonly approved (Billig, 2001), resulting in a mystification of the historical and political facts as told by the majority. The attempt to introduce a positive perception of some fundamental factors of the historical Fascism is used as tool for"historical legitimation for the central aspects of the political claims", 
a "piece of the past programmatically recovered, on which they grow aspects analogous of the actual right extremism" (Holzer, 2001, p. 28).

\section{LR Strategy for the Ingroup: The Sense of Affiliation and the Discrimination of the Outgroup}

The newsgroup is an environment of asynchronous CMC that allows a participative and dialogic communication style. Newsgroup discourse is a collective conversation involving multiple voices (Ligorio, 2002; Mininni, 2003). From this point of view, newsgroups provide affordances to share an enormous massive structure of information and to hold a dialogue with a lot of people sharing common interests and mutual social engagements.

Besides, such discursive productions create a "local social structuring of semiotic differences" in the textual environment (Fairclough, 2001, p. 240) which, according to the proposed model, is in relationship with the differences of discourse that ER groups build into their communicative activities.

In the newsgroups, interaction primarily occurs among ER ingroup members, who accomplish a series of actions involving voluntary participation. First of all they register to the newsgroup, which is different from the accidental visiting of web sites. In this environment, identity construction is grounded on a system of beliefs and shared attitudes that are not argued, because they don't need to be debated. Their function is to confirm a positive identity for the group, showing a marked differentiation from the outgroup which is clearly devalued in an old-fashioned, extremely aggressive manner.

In newsgroups, where the members of the ingroup join in the active search for partners sharing the same orientation, the vocabulary is clearly polarized (LR) and it draws into the ER interpretative repertoire, so that the terms also assume the value of signal of affiliation. The fact that the newsgroups analysed are a communication product addressed to members of the ER area of militancy is clearly evidenced by the content and style of the messages posted. The messages refer to the ER system of beliefs and knowledge, and claim to share "history, values, martyrs".

The complementary aspect of the argumentative strategy affecting the newsgroups is the negation of outgroup values and the devaluation of whole groups, or their members, as carriers of such values. The ER defines its enemies: United States, Jews, Communists, often united in an whole entity with the use of the argument of the conspiracy theory, and more recently, Muslims, as in the following utterances:

<Italy is economically in the shit, and then ... alliances are tightened with (Americans) dogs and hogs (Zionists) $)^{8}>$
$<$ Let's free the society from the Red dregs, to all the levels, as you do with the weeds parasites in the wheat fields ${ }^{9}>$

$<$ Dear Daniel, in a little while we will be circumcised and greet each other by saying "sciallomme sciallomme", or greeting doing: "To salamm aleicum" and you of rhyming "Aleicum to salamm" ${ }^{10}>$

\section{Conclusions}

The cultural, historical and social conditions that allowed the advent of the Fascist and Nazi regimes in the first half of the $20^{\text {th }}$ century cannot be repeated in Europe. Such ideas as ethnic purity, racial hate, wars of aggression and conquest are negated by common sense.

Nevertheless, the events which occurred in the Balkans show how ethnic conflicts in which militant groups recalling the ideology of ER can play a significant role (Byford \& Billig, 2001; Luverà, 1999) can still explode close to the European Union. Psychology always has extreme difficulty in explaining to a large public how it is possible for common people to be capable of the kind of atrocities committed during World War II, in the Balkans or in Rwanda. Reasons have been sought in individual psychology or in group dynamics. So many theories have been formulated that a barely partial review of the literature would need a space ad hoc.

Identity construction as "position taking" (Serino, 2001) faced with the rapid evolution of the social context, and of migratory and globalization processes become a key explanatory factor for contemporary social psychology. Nevertheless post-modern identity is an extremely complex and fragmentary product, which finds in the environments of CMC the conditions of "fluidity" (for a review of the topic see Annese, 2002).

ER groups play an important role in the social dynamics of the new century and, anchoring themselves to the deepest anguishes consequential to the disorientation of given social identities, become emergent actors in political and social scenarios. Such a process of legitimation and identity reconstruction appears all the more remarkable as it is embedded in a socio-economic context that confronts some classes of Italian society with problems of identity and orientation.

As long as such problems exist, they are also faced with the necessity of recurring to an identification with national history and to an increased awareness of their "cleaned up" traditions (Holzer, 2001, p. 27).

Through the lens of the RP paradigm, the analysis illustrated here has underlined, via the different contexts of CMC, how ER groups make use of identity strategies that can be explained by the "dual strategy" model. The attempt of producing an alternative discourse and a new 
identity means challenging the norms and the social order that produced the mainframe discourse (Fairclough, 1992). It also means challenging the ownership of sense making (Wenger, 1998) which is prerogative of specific social actors in a given social context. It is the case of revisionist discourse, aiming at challenging both the mainframe discourse on historical events and the right to speak the truth about history. Such strategies are anchored to the ideological reference system and inter-organisational context of the ER groups (Figure 5). The declension of cultural models of reference is carried out in relation to the environment (sites $-\mathrm{v}-$ newsgroup), the type of audience (ingroup $-\mathrm{v}-$ outgroup) and function (positive self-presentation $-v-$ maintenance of the identity). In turn, identity construction plays a pragmatic function, influencing the judgments and beliefs of common sense aim of making ER ideology acceptable. This circular relationship between identity and ideology immediately evokes the theoretical principles of the cultural psychology (Cole, 1996). The present study therefore combines a social approach to the psychology of CMC, formulating the theme of the identity construction in terms of discursive dynamics rather than on intra-individual cognitive processes.

The illustrated results find an indirect confirmation in Moscovici's "active minorities" theory (1979) which we mention here only in passing and which has been considered in a different study (Tateo, 2006). The key factor of success in the dynamics of minority influence is the "style of behaviour" (Moscovici, 1979, p. 129), which is the organization of behavioural dynamics and the intensity of their expression. The style of behaviour is a pragmatic concept: the "rhetoric of the behaviour and the opinion" (Moscovici, p. 129). The adoption of a style of behaviour plays a double function: it defines the subject, individual or group (identity function), and it provides information directed to modify attitudes towards the subject (instrumental function). The characteristics a style of behaviour must possess in order to be effective are coherence, certainty, and intensity, and it must also be systematic (Moscovici, p. 130). ER groups are fully compliant with these characteristics in their on-line activities (Tateo, 2006). They pretend to be rooted in public opinion, and exploit the virtual impossibility of checking whether all groups present within a web site are as numerous as they claim to be (Cavina, 2001).

The discursive productions of web sites therefore assume identity, instrumental and ideological functions. The digital artefact plays a very important role as an implementation tool of the style of behaviour of ER groups. These groups present themselves, at least virtually, as one "nomic minority" (Moscovici, 1979): that is a united and coherent network of groups, which build a dual identity, trying to modify common sense and public opinion, through specific discursive dynamics.

The issues discussed here naturally require a more indepth theoretical review, but nevertheless it seems that we have contributed an opportunity to reflect on the processes of identity and the ideological declension of ER groups acting in different $\mathrm{CMC}$ environments. Moreover, we hope to have made clear that the study of ER communication via computer networks requires a constant interaction with cultural, political and ideological context (Wodak, 2002), as well as theoretical and methodological enrichment with respect to different psychological and sociological perspectives (Tateo, 2005, 2006).

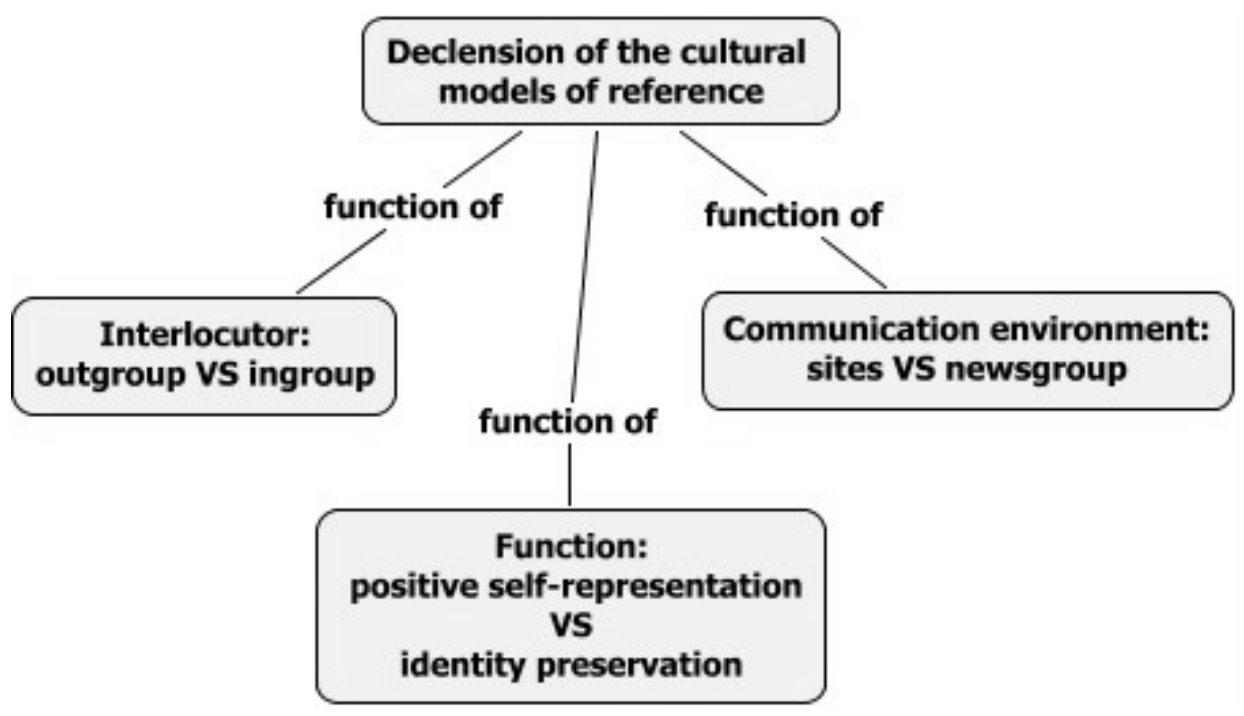

Figure 5. Argumentative strategies in Computer mediated communication 


\section{Notes}

1. Thanks to professor Susanna Annese for her tutorship. Thanks to professors Mininni and Bellelli and to the scientific board of the Doctorate in Psychology of Communication at the University of Bari (Italy) for supporting and encouraging me in my $\mathrm{PhD}$ research, the present work is a development. Thanks to Wilma Clark for the revision of the English language.

2. A "webring" is a network of web sites that are linked each other. Starting from a single site page you can always access all the others following the links of the chain.

3. In Italian: "alleanza italica on-line".

4. In Italian: "I reduci di tale epica resistenza furono rinchiusi in campi di concentramento a Taranto, Scandicci, Coltano etc." $(2 / 44 / 370)$.

5. In Italian: "DECINE DI TESTIMONIANZE "Desaparecidos" di casa nostra. Movimento per la libertà o per la sovietizzazione dell'Italia?"' (2/44/262).

6. In Italian: "Allora... diamo una chance all' interpretazione futura! Raccontiamo anche l'"altra storia". E se anche non fosse tutta vera o tutta giusta sarà sempre una possibilità in più per capire come andarono le cose. Per chi onestamente vorrà ascoltare" (2/39/48).

7. In Italian: "I " Fascismi “, dunque, sono fede e ragione, passione e buon senso. Fede irremovibile che travalica spiritualmente ogni intendimento umano e semplice ragione che riconduce $i$ sogni al senso della loro effettiva e possibile realizzazione" (1/ 143/47).

8. In Italian: "No, l'Italia è economicamente nella merda, e allora ... si stringono o si ammiccano alleanze con (ameri)cani e porci (sionisti)" (1/460).

9. In Italian: "Liberiamo la società dalla feccia rossa, a tutti $i$ livelli, come si fa con le erbacce parassite nei campi di grano" $(2 / 408)$.

10. In Italian: "Caro Daniele tra un po' ci toccherà mozzarci il pene e salutarci facendo sciallomme sciallomme, oppure salutandoci facendo: 'A salamm aleicum' e tu di rimando 'Aleicum a salamm”' (1/462).

\section{References}

Annese, S. (2002). The discursive multiplication of identity in CMC (La moltiplicazione discorsiva dell'identità nella $\mathrm{CMC}$ ). In G. Mininni (Ed.), Virtuale.com (pp. 61-96). Naples, Italia: Idelson-Gnocchi.

Bazerman, C. (1994). Systems of genres and the enactment of social intentions. In A. Freedman \& P. Medway (Eds.), Genre and the new rhetoric (pp. 79-101). London: Taylor.

Bernstein, L. (1996). L'extrême droite sur internet (CRIDA Rapport 1996). Paris: Panorama des Actes Racistes et de L’Extrémisme de Droite en Europe.

Byford, J. T., \& Billig, M. (2001). The emergence of anti-Semitic conspiracy theories in Yugoslavia during the war with NATO. Patterns of Prejudice, 35(4), 50-63.

Billig M. (1977). The new Social Psychology and "fascism". European Journal of Social Psychology, 4, 393-432.

Billig, M. (1996). Arguing and thinking: A rhetorical approach to Social Psychology (Rev. ed.). Cambridge, UK: Cambridge University Press.

Billig, M. (2001). Humor and hatred: The racist jokes of the Ku
Klux Klan. Discourse \& Society, 12(3), 267-289.

Burris, V., Smith, E., \& Strahm, A. (2000). White supremacist network on the internet. Sociological Focus, 33(2), 215-235.

Cavina, E. (2001, November 17). The black pages: Information and communication on the "unified" world of the web (Le pagine nere: informazione e comunicazione nel mondo "unificato" del web). In Istituto Storico della resistenza e dell'età contemporanea in Ravenna e Provincia (Ed.), Atti del convegno di studi Le Nuove Destre: movimenti radicali in Europa (pp. 71-84). Ravenna, Italia: Moderna.

Cole, M. (1996). Cultural Psychology. Cambridge, MA: Harvard University Press.

December, J. (1996). Unit of analysis for internet communication. Journal of Communication, 46(1), 43-63.

Dyson, E. (1997). Release 2.0: A design for living in the digital age New York: Broadway Books.

Evans, J., Arzheimer, K., Baldini, G., Bjoklund, T., Carter, E., Fisher, S., \& Ivaldi, G. (2001). Comparative mapping of extreme right electoral dynamics: An overview of extreme right electorates and party success. European Political Sciences, 1(1),

Fairclough, N. (1992). Discourse and social change. Cambridge, UK: Polity.

Fairclough, N. (1995). Media discourse. London: Arnold.

Fairclough, N. (2000). Discourse, social theory, and social research: The discourse of welfare reform. Journal of Sociolinguistics, 4(2), 163-195.

Fairclough, N. (2001). The discourse of new labour: Critical discourse analysis. In M. Wetherell, S. Taylor, \& S. J. Yates (Eds.), Discourse as data. A guide for analysis. London: Sage.

Flowerdew, J. (1998). The final years of British Hong Kong: The discourse of colonial withdrawal. London: Macmillan.

Flowerdew, J. (1999). Description and interpretation in critical discourse analysis. Journal of Pragmatics, 31, 1089-1999.

Flowerdew, J. (2004). The discursive construction of a world-class city. Discourse \& Society, 15(5), 579-605.

Franklin, R. A. (2006). The hate directory. Retrieved September 9, 2006, from http://www.bcpl.net/ rfrankli/hatedir.pdf

Gerstenfeld, P. B., Grant, D. R., \& Chiang, C. (2003). Hate online: A content analysis of extremists Internet sites. Analyses of Social Issues and Public Policy, 3(1), 29-44.

Glaser, J., Dixit, J., \& Green, D. P. (2002). Studying hate crime with the internet: Racists advocate racial violence. Journal of Social Issues, 38(1), 177-193.

Gilbert, G. N., \& Mulkay, M. (1984). Opening Pandora's Box: A sociological analysis of scientists' discourse. Cambridge, UK: Cambridge University Press.

Herring, S. (Ed.). (1996). Computer-mediated communication: Linguistic, social and cross-cultural perspectives. Amsterdam, Nederland: John Benjamins.

Hoffman, D. S. (1996). The web of hate: Extremists exploit the internet. New York: Anti Defamation League.

Holzer, W. (2001, November 17). Right extremism: Phenomenology, fascination and identification of actual political proposals (Estremismo di destra: fenomenologia, fascinazione e identificazione dell'attuale proposta politica). In Istituto Storico della resistenza e dell' età contemporanea in Ravenna e Provincia (Ed.), Atti del convegno di studi Le Nuove Destre: movimenti radicali in Europa (pp. 17-45). Ravenna, Itália: Moderna.

Karmasyn, G., Panczer, G., \& Fingerhut, M. (2000). Le négationnisme sur internet. Genèse, stratégies, antidotes. Revue d'histoire de la Shoah, 170.

Lakoff, R. (1990). Talking power: The politics of language. New York: Harper Collins. 
Levin, B. (2002). Cyberhate: A legal and historical analysis of extremists' use of computer networks in America. American Behavioral Scientist, 45, 958-988.

Lewis Rand, C. (1996). The neo-nazis and german unification. Berlin, Germany: Praeger.

Ligorio, M. B. (2002). Cognitive and relational aspects of problem solving in CMC environment (Aspetti cognitivi e relazionali del problem solving in ambiente di CMC). In G. Mininni (Ed.), Virtuale.com (pp. 97-122). Naples, Italia: Idelson-Gnocchi.

Luverà, B. (1999). The borders of hate. Ethnic nationalism and the new European right (I confini dell'odio. Il nazionalismo etnico e la nuova destra Europea). Rome, Italia: Riuniti.

Markova, I. (2003). Dialogicality and social representations. Cambridge, UK: Cambridge University Press.

McDonald, M. (1999). Cyberhate: Extending persuasive techniques of low credibility sources to the world wide web. In D. W. Schumann \& E. Thorson (Eds.), Advertising and the world wide web (pp. 149-175). Mahwah, NJ: Lawrence Erlbaum.

Mininni, G. (2003). The psycho-semiotic approach, texts and images (L'approccio psicosemiotico, testi e immagini). In G. Mantovani \& A. Spagnolli (Eds.), Metodi qualitativi in Psicologia (pp. 159-197). Bologna, Italia: il Mulino.

Moscovici, S. (1979). Psychologie de minorités actives. Paris: PUF.

Perelman, C., \& Olbrechts-Tyteca, L. (1969). The new rhetoric: A treatise on argumentation. Paris: University of Notre Dame Press.

Schmidt, M. (1993). Néo-nazis. Milano, Italia: Rizzoli.

Serino, C. (2001). Paths of the self. New scenarios for Social Psychology and identity (Percorsi del Sè. Nuovi scenari per la Psicologia Sociale dell'Identità). Rome, Italia: Carocci.

Sherif, M., \& Hovland, C. I. (1961). Social judgement. New Haven, CT: Yale Univeristy Press.

Shermer, M., \& Grobman, A. (2000). Who says the holocaust never happened and why do they say it? Los Angeles, CA: University of California Press.

Stern, K. S. (1999). Hate and the internet. New York: American Jewish Committee.

Tadmor-Shimony, T. (1995). Anti-semitism on the information superhighway: A case study of a UseNet Discussion Group. Jerusalem, Israel: Vidal Sassoon International Center for the Study of Anti-Semitism.

Tateo, L. (2002). Communication strategies of Extreme Right Groups via the internet. A preliminary research on Italian Extreme Right Web Sites. In K. Petrova (Ed.), Litora Psycholinguistica (pp. 154-163). Sofia, Bulgary: Sema Publishing House.

Tateo, L. (2005). The Italian extreme right on-line network: An exploratory study using an integrated social network analysis and content analysis approach. Journal of Computer-Mediated Communication, 10(2). Retrieved January 15, 2005, from http:/ /jcmc.indiana.edu/vol10/issue2/tateo.html

Tateo, L. (2006). Changing representations of "Good" and "Evil": How minority extreme right groups act in computer mediated communication environment. Paper presented at $8^{\text {th }}$ International Conference on Social Representations, Rome, Italia.

Wenger, E. (1998). Communities of practice: Learning, meaning and identity. Cambridge, UK: Cambridge University Press.

Wetherell, M., Taylor, S., \& Yates, S. J. (Eds.). (2001). Discourse as data. A guide for analysis. London: Sage.

Wodak, R. (2002). Friend or foe: The defamation or legitimate and necessary criticism? Reflections on recent political discourse in Austria. Language \& Communication, 22, 495-517.

Wodak, R., \& Meyer, M. (Eds.). (2001). Methods of critical discourse analysis. London: Sage.
Luca Tateo is Ph.D. in Psychology of Communication at the University of Bari (Italy). He is currently professor of Department of Education Sciences of University of

Salerno and coordinator of the Center for Documentation of Job Market and Southern Italian Policies and the Employment Center of the municipality of Salerno. Address: Via Ponte Don Melillo, Fisciano

(SA), Italy, I-84084. Phone: +39089 798263. ltateo@unisa.it

The "Fascist" Discourse in Computer Mediated Communication: the "dual strategy" model of the Italian extreme right

Luca Tateo

Recebido: 26/02/2008

$1^{\mathrm{a}}$ revisão: $10 / 07 / 2008$

Aceite final: 12/07/2008 